\title{
Pertumbuhan dan Kelangsungan Hidup Benih Ikan Gurami yang Diberi Pakan Mengandung Bunga Rosella dengan Dosis yang Berbeda
}

\section{Growth and Survival of Giant Gouramy Fry Had Been Feed that Contain Roselle with Different Dosage}

\section{Laela Nurhafiah, Rosmawati dan Mulyana}

\begin{abstract}
The aim of this research to determine the dosage of roselle (Hibiscus sabdariffa L.) that produce the best growth and survival of giant gouramy (Osphronemus gouramy Lac.) fry. This research was using the completely randomized design with 3 treatments. The treatments are $20 \mathrm{~g}$ of roselle $/ \mathrm{kg}$ of feed, $30 \mathrm{~g}$ of roselle $/ \mathrm{kg}$ of feed and control $(0 \mathrm{~g}$ of roselle $/ \mathrm{kg}$ of feed). The size of giant gouramy fry is $2-3 \mathrm{~g}$. The stocking density of giant gouramy fry is 40 fish/aquarium. The daily growth rate, survival rate, and food efficiency had been evaluated. The results of the research showed that the use of roselle produced the significantly different $(\mathrm{P}<0.05)$ against the daily growth rate, survival rate and food efficiency of giant gouramy fry. The best dosage of roselle is $20 \mathrm{~g}$ of roselle/kg of feed with $1.041 \%$ of daily growth rate, $68.00 \%$ of survival rate, and $17.729 \%$ of food efficiency.
\end{abstract}

Key words: giant gouramy fry, roselle, daily growth rate, survival rate

\begin{abstract}
ABSTRAK
Penelitian ini bertujuan untuk mengetahui dosis bunga rosella (Hibiscussabdariffa L.) yang akan menghasilkan pertumbuhan dan kelangsungan hidup terbaik benih ikan gurami (OsphronemusgouramyLac.).Rancangan percobaan dalam penelitian ini adalah Rancangan Acak Lengkap dengan 3 perlakuan. Perlakuan yang diberikan adalah dosis rosella yang berbeda, yaitu : perlakuan A (0 g rosella/kg pakan), perlakuan B (20 g rosella/kg pakan), dan perlakuan C (30 g rosella/kg pakan). Ikan yang digunakan adalah benih ikan gurami dengan ukuran 2-3 g dengan padat tebar 40 ekor/akuarium. Parameter percobaan yang diamati selama penelitian adalah laju pertumbuhan harian, derajat kelangsungan hidup, efisiensi pakan. Hasil penelitian mempertunjukkan bahwa pemberian pakan dengan kandungan rosella yang berbeda memberikan pengaruh yang signifikan $(\mathrm{P}<0,05)$ terhadap laju pertumbuhan harian, derajat kelangsungan hidup, dan efisiensi pakan. Perlakuan pemberian dosis $20 \mathrm{~g}$ rosella/kg pakan menghasilkan laju pertumbuhan harian, derajat kelangsungan hidup, dan efisiensi pakan terbaik yaitu 1,041\%, $68,88 \%, 17,729 \%$.
\end{abstract}

Kata kunci : Ikan gurami, bunga rosella, pertumbuhan, kelangsungan hidup

Laela Nurhafiah, Rosmawati, Mulyana. 2017. Pertumbuhan dan Kelangsungan Hidup Benih Ikan Gurami yang Diberi Pakan Mengandung Bunga Rosella dengan Dosis yang Berbeda. Jurnal Mina Sains 3(2): 14-22.

\section{PENDAHULUAN}

\section{Latar Belakang}

Ikan gurami adalah salah satu ikan asli perairan Indonesia. Ikan ini mempunyai nilai ekonomi penting dan sudah dibudidayakan seperti jenis ikan ekonomis lainnya. Ikan gurami menjadi komoditas unggulan bagi masyarakat karena selain produk benihnya telah membentuk segmentasi pemasaran yang baik, ikan gurami konsumsi diminati segala kalangan (Saparinto 2011).

Ikan gurami memiliki pertumbuhan agak lambat dibandingkan ikan air tawar lainnya. Namun, ikan tersebut digemari masyarakat. Kebutuhan ikan gurami mengalami kenaikan setiap tahunnya. Meskipun pertumbuhan badan gurami relatif lama, namun pasarnya cukup 
menggiurkan. Oleh sebab itu tidak salah bila ikan gurami harus terus dikenalkan dan dikembangkan oleh masyarakat (Saparinto 2011).

Pakan ikan yang baik adalah memiliki komposisi zat gizi yang lengkap seperti protein, lemak, karbohidrat, vitamin, dan mineral. Bunga rosella mengandung vitamin A dan vitamin $C$ yang cukup tinggi dibandingkan buah-buahan lainnya, kadar vitamin $\mathrm{C}$ sebanyak 214,68 mg per 100 gram ekstrak rosella. Vitamin $\mathrm{C}$ sangat dibutuhkan karena vitamin $\mathrm{C}$ bisa memicu pertumbuhan, memicu imunitas terhadap serangan penyakit, dan mengatasi stres (Mardiah et al. 2009).

Komposisi zat gizi pakan yang seimbang akan meningkatkan pertumbuhan ikan (Tiana dan Murhananto 2004). Sedangkan pertumbuhan tergolong aspek penting yang dipelajari dalam dunia perikanan karena pertumbuhan menjadi indikator bagi kesehatan individu dan populasi yang baik bagi ikan (Effendie 2002). Oleh karena itu, perlu dilakukan penelitian untuk mengetahui pertumbuhan dan kelangsungan hidup ikan gurami yang diberi pakan mengandung bunga rosella.

\section{Tujuan Penelitian}

Penelitian ini bertujuan untuk mengetahui dosis bunga rosella yang akan menghasilkan pertumbuhan dan kelangsungan hidup terbaik benih ikan gurami.

\section{Hipotesis}

Semakin tinggi dosis bunga rosella sampai batas tertentu, maka pertumbuhan dan kelangsungan hidup benih ikan gurami semakin tinggi.

\section{BAHAN DAN METODE \\ Waktu dan Tempat}

Penelitian ini dilakukan pada bulan Maret-Juni 2013 dengan masa percobaan dari 04 Mei-06 Juni 2013, bertempat di Laboratorium Perikanan, Universitas Djuanda Bogor.

\section{Alat dan Bahan}

Alat yang digunakan adalah dua belas unit akuarium berukuran $50 \mathrm{~cm}$ x $30 \mathrm{~cm}$ x 30 $\mathrm{cm}$, heater, bokhlam lampu, blower, dan timbangan digital. Peralatan laboratorium untuk menghaluskan bunga rosella yang digunakan yaitu oven, blender, wadah, dan saringan.

Bahan yang digunakan adalah 480 ekor ikan gurami dengan ukuran 2-3 gram, bunga rosella, dan pakan ikan berbentuk tepung. Pakan yang digunakan sebelumnya dicampur dengan bunga rosella sesuai dengan dosis perlakuan. Bunga rosella yang digunakan terlebih dahulu dijadikan tepung dengan cara bunga rosella dikeringkan menggunakan oven pada temperatur $50^{\circ} \mathrm{C}$ selama 24 jam, kemudian dihaluskan menggunakan blender dan selanjutnya disaring menggunakan alat saringan. Bahan dan alat lainnya yaitu untuk analisis kualitas air: suhu, $\mathrm{pH}, \mathrm{DO}, \mathrm{CO}_{2}$, dan $\mathrm{NH}_{3}$.

\section{Prosedur Penelitian \\ Persiapan Penelitian}

Akuarium yang akan digunakan dibersihkan dan dikeringkan dulu, kemudian diisi air sebanyak 34 liter. Setelah semua akuarium terisi air dilanjutkan pemasangan aerasi tujuannya untuk meningkatkan kandungan oksigen terlarut (DO) kemudian pemasangan heater dan boklam lampu agar air tetap stabil pada suhu $28-30{ }^{\circ} \mathrm{C}$.

Ikan gurami diadaptasi selama satu minggu terhadap pakan buatan, setelah itu kemudian dilakukan sampling ukuran ikan. Ikan yang ukurannya sesuai dengan percobaan dimasukkan ke akuarium percobaan dengan kepadatan 40 ekor/ akuarium.

\section{Pelaksanaan Percobaan}

Ikan gurami dipelihara dalam akuarium selama 30 hari. Selama pemeliharaan tersebut ikan diberi pakan sesuai perlakuan. Pemberian pakan dilakukan secara ad libitum dan frekuensi pemberian pakan dua kali sehari, yaitu pada jam 08.00 dan 16.00 WIB.

Sumber air yang dipakai berasal dari air tanah yang kemudian diendapkan dan diberi aerasi terlebih dahulu selama tiga hari. Untuk menjaga kualitas air dalam akuarium agar tetap stabil, dilakukan penyiponan setiap hari dan penambahan air. Penyiponan dilakukan dengan cara mengangkat sisa pakan dan kotoran hasil metabolisme benih ikan gurami sebanyak 50\% dari total air dalam akuarium dan penambahan 
air tandon sebanyak yang diperlukan. Penyiponan dilakukan pada jam 07.00 dan 16.00 WIB sebelum ikan diberi pakan.

Ikan gurami ditimbang pada awal dan akhir penelitian tujuannya untuk mendapatkan nilai pertambahan bobot ikan gurami sehingga didapat nilai laju pertumbuhan harian. Selain itu dihitung jumlah pakan yang dimakan selama percobaan dan jumlah ikan pada akhir percobaan.

\section{Rancangan Percobaan}

Rancangan percobaan dalam penelitian ini adalah Rancangan Acak Lengkap dengan 3 perlakuan dan ulangan yang berbeda. Perlakuan A dan B diulang 4 kali, sedangkan perlakuan $\mathrm{C}$ diulang 3 kali. Perlakuan yang diberikan adalah dosis rosella yang berbeda, yaitu: Perlakuan A (pakan tanpa penambahan bunga rosella $0 \mathrm{~g} / \mathrm{kg}$ pakan), Perlakuan $\mathrm{B}$ (pakan dengan penambahan bunga rosella 20 $\mathrm{g} / \mathrm{kg}$ pakan), dan Perlakuan C (pakan dengan penambahan bunga rosella $30 \mathrm{~g} / \mathrm{kg}$ pakan). Analisis data dilakukan dengan model statistika berdasarkan Sastrosupadi (1995) :

dimana:

$$
\boldsymbol{Y} \boldsymbol{i j}=\boldsymbol{\mu}+\boldsymbol{T i}+\varepsilon \boldsymbol{i j}
$$

$\boldsymbol{Y} \boldsymbol{i} \boldsymbol{j}=$ Respon atau nilai pengamatan dari perlakuan ke-i dan ulangan ke-j

$\boldsymbol{\mu}=$ Nilai tengah umum

$\boldsymbol{T} \boldsymbol{i}=$ Pengaruh perlakuan ke-i

$\boldsymbol{\varepsilon} \boldsymbol{i} \boldsymbol{j}=$ Pengaruh galat percobaan dari perlakuan ke-i dan ulangan ke-j.

$\boldsymbol{i}=$ Perlakuan $(\mathrm{A}, \mathrm{B}, \mathrm{C})$

$\boldsymbol{j}=$ Ulangan $(\mathrm{A}$ dan $\mathrm{B}=1,2,3,4$ sedangkan $\mathrm{C}=1,2,3$ )

\section{Parameter yang Diukur Laju Pertumbuhan Harian}

Laju pertumbuhan harian benih ditentukan berdasarkan rumus dari Huisman (1987) dalam Darmansyah (2011) sebagai berikut:

dimana:

$$
\alpha=\left[\sqrt{\frac{W t}{W 0}}-1\right] \times 100 \% t
$$

$\alpha=$ Laju pertumbuhan harian (\%)

$W t=$ Bobot rata-rata ikan uji pada akhir percobaan $(\mathrm{g})$

$W o=$ Bobot rata-rata ikan uji pada awal percobaan $(\mathrm{g})$ $t \quad=$ Waktu pemeliharaan ikan (hari)

\section{Derajat Kelangsungan Hidup}

Derajat kelangsungan hidup yaitu dengan membandingkan jumlah ikan yang hidup pada akhir suatu periode dengan jumlah ikan yang hidup pada awal periode. Derajat kelangsungan hidup dihitung berdasarkan rumus dari Effendie (1979) yaitu:

dimana:

$$
\mathrm{S}=\frac{N t}{N o} x 100 \%
$$

$\mathrm{S}=$ Derajat kelangsungan hidup (\%)

$N t=$ Jumlah ikan pada akhir penelitian (ekor)

$N o=$ Jumlah ikan pada awal penelitian (ekor)

\section{Efisiensi Pakan}

Efisiensi pakan dapat diketahui antara lain dari konversi, yaitu nilai perbandingan antara berat pakan yang diberikan dan pertambahan berat ikan. Efisiensi pakan dihitung dengan menggunakan rumus dari Effendie (1979):

$$
\operatorname{EP}(\%)=\frac{(\boldsymbol{W t}+\boldsymbol{d})-\boldsymbol{W o}}{F} X 100 \%
$$

dimana:

$\mathrm{EP}=$ Efisiensi pakan $(\%)$

$\mathrm{F}=$ Jumlah pakan yang diberikan $(\mathrm{g})$

$W t=$ Bobot ikan pada akhir pemeliharaan $(\mathrm{g})$

$W o=$ Bobot ikan pada awal pemeliharaan $(\mathrm{g})$

$d=$ Bobot ikan yang mati $(\mathrm{g})$

\section{Kualitas Air}

Pengukuran kualitas air dilakukan di awal dan akhir penelitian kecuali suhu dan $\mathrm{pH}$ tujuannya untuk mengetahui air dalam keadaan optimal untuk benih ikan gurami atau tidak karena kualitas air yang baik merupakan salah satu faktor penentu bagi keberhasilan proses budidaya ikan. Jika didukung dengan kualitas air yang baik, maka pertumbuhan ikan akan cepat. Parameter kualitas air yang diukur adalah suhu, $\mathrm{pH}, \mathrm{DO}, \mathrm{CO}_{2}$, dan $\mathrm{NH}_{3}$.

\section{Analisis Data}

Analisis data yang digunakan selama penelitian yaitu analisis ragam (ANOVA) dan apabila $F_{\text {hitung }}$ berbeda nyata, maka untuk mengetahui perbedaan antar perlakuan dilakukan menggunakan uji BNT (Beda Nyata Terkecil) (Sastrosupadi 1995). 
Hasil

\section{HASIL DAN PEMBAHASAN}

\section{Laju Pertumbuhan Harian Benih Ikan Gurami}

Laju pertumbuhan harian tertinggi selama percobaan yaitu ditemukan pada perlakuan 20 dan $30 \mathrm{~g}$ rosella/kg pakan sebesar $1,041 \%$ dan $1,047 \%$ sedangkan laju pertumbuhan harian terkecil diperoleh pada perlakuan pakan tanpa rosella sebesar 0,483\%. Rataan laju pertumbuhan harian (\%) gurami selama percobaan tercantum pada Tabel 1 .

Tabel 1 Laju pertumbuhan harian (\%) rata-rata benih ikan gurami

\begin{tabular}{cccc}
\hline Ulangan & \multicolumn{3}{c}{ Dosis Rosella (g/kg pakan) } \\
\cline { 2 - 4 } & 0 & 20 & 30 \\
\hline $\mathbf{1}$ & 0,476 & 0,941 & 1,171 \\
$\mathbf{2}$ & 0,575 & 1,400 & 1,082 \\
$\mathbf{3}$ & 0,646 & 0,678 & \\
$\mathbf{4}$ & 0,233 & 1,143 & 0,888 \\
\hline Rata-rata & $0,483^{\mathrm{a}}$ & $1,041^{\mathrm{b}}$ & $1,047^{\mathrm{b}}$ \\
\hline
\end{tabular}

Hasil ANOVA memperlihatkan bahwa pemberian pakan dengan dosis rosella yang berbeda yaitu pakan kontrol, $20 \mathrm{~g}$ rosella/kg pakan, dan $30 \mathrm{~g}$ rosella/kg pakan memberikan pengaruh yang signifikan antar perlakuan pada taraf $95 \%(\mathrm{P}<0,05)$ terhadap laju pertumbuhan harian benih ikan gurami. Uji lanjut dengan Beda Nyata Terkecil (BNT) menunjukkan bahwa perlakuan pakan tanpa rosella berbeda dengan perlakuan 20 dan $30 \mathrm{~g}$ rosella/kg pakan, sedangkan perlakuan 20 dan $30 \mathrm{~g}$ rosella/kg pakan sama.

Tabel 2 Kelangsungan hidup (\%) benih ikan gurami

\section{Derajat Kelangsungan Hidup Benih Ikan Gurami}

Derajat kelangsungan hidup benih ikan gurami tertinggi terajadi pada perlakuan 20 dan $30 \mathrm{~g}$ rosella/kg pakan sebesar $68,88 \%$ dan $72,50 \%$ sedangkan derajat kelangsungan hidup terendah ditemukan pada perlakuan pakan tanpa rosella 50,00 \%. Derajat kelangsungan hidup (\%) benih ikan gurami selama masa percobaan dapat dilihat pada Tabel 2.

\begin{tabular}{cccc}
\hline Ulangan & \multicolumn{3}{c}{ Dosis Rosella $(\mathbf{g} / \mathbf{k g}$ pakan) } \\
\cline { 2 - 4 } & 0 & 20 & 30 \\
\hline $\mathbf{1}$ & 47,50 & 60,00 & 87,50 \\
$\mathbf{3}$ & 52,50 & 65,00 & 75,00 \\
$\mathbf{4}$ & 45,00 & 67,50 & 55,00 \\
\hline Rata-rata & 55,00 & 75,00 & $72,50^{\mathrm{b}}$ \\
\hline
\end{tabular}

Keterangan : Angka yang diikuti huruf yang sama pada baris yang sama menunjukkan tidak berbeda nyata $(\mathrm{P}>0,05)$

Hasil uji ANOVA menunjukkan bahwa pemberian dosis rosella yang berbeda memberikan pengaruh yang signifikan pada taraf $95 \% \quad(\mathrm{P}<0,05)$ terhadap derajat kelangsungan hidup benih ikan gurami. Berdasarkan uji lanjut BNT pada perlakuan pakan tanpa rosella berbeda nyata dengan perlakuan 20 dan $30 \mathrm{~g}$ rosella/kg pakan, sedangkan perlakuan 20 dan $30 \mathrm{~g}$ rosella/kg pakan sama.

\section{Efisiensi Pakan Benih Ikan Gurami}

Efisiensi pakan tertinggi terdapat pada perlakuan 20 dan $30 \mathrm{~g}$ rosella/kg pakan sebesar
$17,729 \%$ dan $17,754 \%$ sedangkan efisiensi pakan terkecil terdapat pada perlakuan pakan tanpa rosella sebesar 7,696\% (Tabel 3).

Hasil ANOVA memperlihatkan bahwa pemberian dosis rosella yang berbeda berpengaruh nyata antar perlakuan pada taraf $95 \%(\mathrm{P}<0,05)$ terhadap efisiensi pakan benih ikan gurami. Uji lanjut BNT memperlihatkan bahwa perlakuan pakan tanpa rosella berbeda dengan perlakuan 20 dan $30 \mathrm{~g}$ rosella/kg pakan, tetapi pada perlakuan 20 dan $30 \mathrm{~g}$ rosella/kg pakan sama. 
Tabel 3 Efisiensi pakan (\%) benih ikan gurami

\begin{tabular}{cccc}
\hline Ulangan & \multicolumn{3}{c}{ Dosis Rosella $(\mathbf{g} / \mathbf{k g}$ pakan) } \\
\cline { 2 - 4 } & 0 & 20 & 30 \\
\hline $\mathbf{1}$ & 7,655 & 15,546 & 20,526 \\
$\mathbf{2}$ & 9,264 & 25,546 & 17,625 \\
$\mathbf{3}$ & 10,433 & 10,453 & \\
$\mathbf{4}$ & 3,432 & 19,372 & 15,112 \\
\hline Rata-rata & $7,696^{\mathrm{a}}$ & $17,729^{\mathrm{b}}$ & $17,754^{\mathrm{b}}$ \\
\hline
\end{tabular}

Keterangan : Angka yang diikuti huruf yang sama pada baris yang sama menunjukkan tidak berbeda nyata $(\mathrm{P}>0,05)$

\section{Kualitas Air}

Selama kegiatan penelitian, kualitas air untuk ikan gurami masih dalam kisaran hidup Tabel 4 Parameter kualitas air selama masa percobaan

\begin{tabular}{lcccc}
\hline \multirow{2}{*}{ Parameter } & \multicolumn{4}{c}{ Perlakuan } \\
\cline { 2 - 5 } Suhu $\left({ }^{\mathbf{0}} \mathbf{C}\right)$ & $\mathbf{A}$ & $\mathbf{B}$ & $\mathbf{C}$ & Tandon \\
\cline { 2 - 5 } pH & $28-31$ & $28-31$ & $28-31$ & $24-26$ \\
DO (ppm) & $7,0-7,4$ & $7,0-7,4$ & $7,0-7,4$ & $6,5-7,2$ \\
$\mathbf{N H}_{3}(\mathbf{p p m})$ & $4,22-4,41$ & $4,27-4,52$ & $4,40-4,55$ & 3,78 \\
$\mathbf{C O}_{\mathbf{2}}(\mathbf{p p m})$ & $0,030-0,044$ & $0,045-0,047$ & $0,040-0,048$ & 0,003 \\
\hline
\end{tabular}

\section{Pembahasan}

\section{Laju Pertumbuhan Harian}

Laju pertumbuhan harian dengan pemberian dosis rosella yang berbeda pada pakan menunjukkan pertumbuhan yang berbeda pula pada tiap perlakuan. Laju normal ikan gurami. Secara lengkap parameter kualitas air yang diuji selama masa percobaan disajikan dalam Tabel 4.

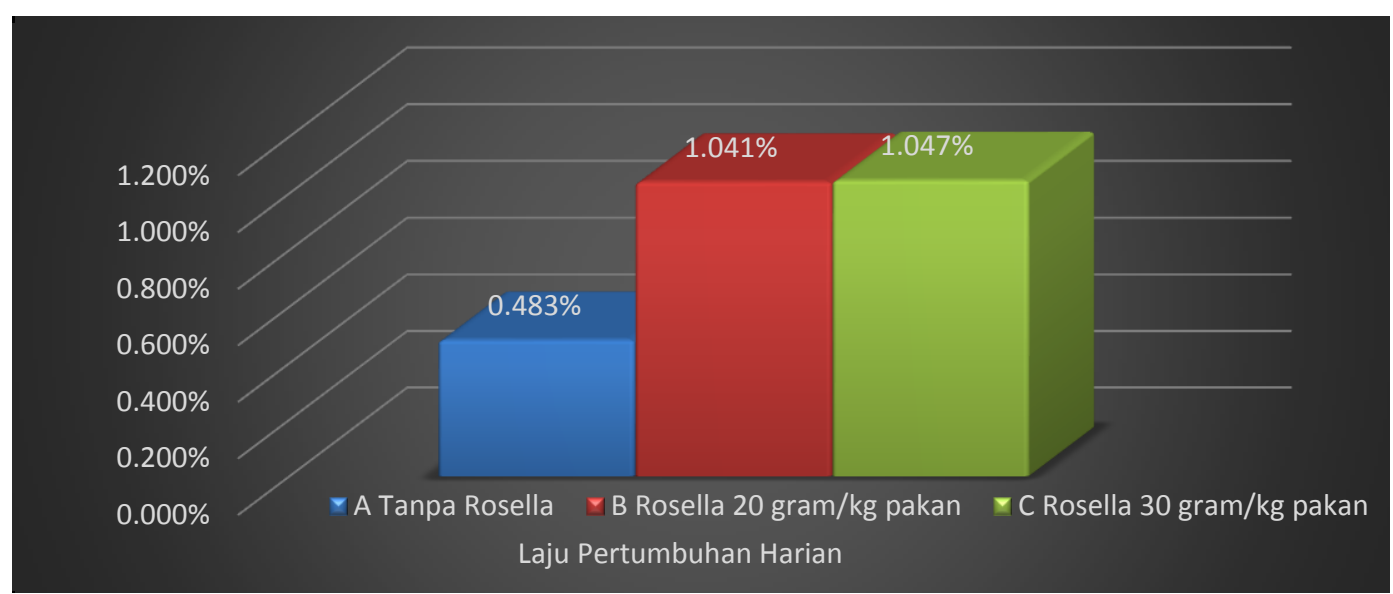

Gambar 1 Laju pertumbuhan harian pada setiap perlakuan selama percobaan

Tabel 1 dan Gambar 1 menunjukkan bahwa pertumbuhan benih ikan gurami yang terendah terdapat pada perlakuan A (pakan tanpa rosella), pakan tanpa pemberian rosella adalah salah satu penyebab pertumbuhan ikan gurami rendah karena rosella mengandung banyak vitamin terutama vitamin $\mathrm{C}$ yang pertumbuhan harian pada setiap perlakuan selama percobaan berbentuk grafik tertera pada Gambar 1. Hasil yang berbeda disebabkan karena pakan yang diberi tambahan rosella mengandung vitamin $\mathrm{C}$ yang cukup untuk pertumbuhan. 
yang terlalu tinggi. SNI : 01-6485.3-2000 menyatakan pemeliharaan benih ikan gurami pada tingkat ukuran 2-4 $\mathrm{cm}$ standar padat tebar yaitu $60 \mathrm{ekor} / \mathrm{m}^{2}$ sedangkan penelitian ini padat tebarnya sekitar 267 ekor/m $\mathrm{m}^{2}$ dengan ukuran yang sama, hal ini dapat berpengaruh terhadap ruang lingkup ikan yang akhirnya berpengaruh terhadap pertumbuhan ikan itu sendiri. Slembrouck et al. (2005) dalam Darmawangsa (2008) menjelaskan padat tebar ikan yang terlalu tinggi dapat menurunkan mutu air, pertumbuhan ikan yang lambat, tingkat kelangsungan hidup ikan yang rendah serta tingkat keragaman ukuran ikan yang tinggi.

Padat tebar yang tinggi dapat menyebabkan benih ikan gurami mengalami stres sehingga berpengaruh terhadap konsumsi makan yang tidak sesuai penggunaannya, yang seharusnya pakan digunakan untuk pertumbuhan dalam hal ini pakan digunakan untuk melawan stres. Pada penelitian ini, banyak pakan yang tidak dimakan selama masa percobaan akibat nafsu makan ikan menurun yang menyebabkan laju pertumbuhan rendah.

Laju pertumbuhan harian tertinggi diperoleh pada perlakuan B (20 g rosella $/ \mathrm{kg}$ pakan) dan $\mathrm{C}$ (30 g rosella/kg pakan), hal ini disebabkan karena perlakuan $\mathrm{B}$ dan $\mathrm{C}$ ditambahkan rosella yang cukup pada pakan yang mengandung vitamin $\mathrm{C}$ yang dapat memicu pertumbuhan sehingga pertumbuhan meningkat. Menurut Lovel (1984), Lee \& Bai (1998) dalam Sandra et al. (2002) menyatakan bahwa vitamin $\mathrm{C}$ dapat meningkatkan pertumbuhan ikan.

Perolehan hasil yang didapat tidak berbeda dengan penelitian sebelumnya (Febrianthi 2012) yang menyebutkan laju pertumbuhan harian tertinggi diperoleh pada perlakuan $20 \mathrm{~g}$ rosella/kg pakan sebesar 2,98 $\%$. Penelitian ini tertinggi pada perlakuan 20 dan $30 \mathrm{~g}$ rosella/kg pakan sebesar $1,041 \%$ dan $1,047 \%$ namun dalam hal ini diambil hasil yang terbaik yaitu pada perlakuan $20 \mathrm{~g}$ rosella/kg, karena lebih ekonomis yang rendah jika hasilnya tidak berbeda. Berdasarkan angka yang dihasilkan berbeda jauh dengan penelitian sebelumnya, hal ini dikarenakan padat tebar yang berbeda antara penelitian sebelumnya dengan penelitian ini. Pada penelitian sebelumnya padat tebar yaitu 167 ekor/m² $\mathrm{m}^{2}$ sedangkan penelitian ini $267 \mathrm{ekor} / \mathrm{m}^{2}$, hal di atas dapat menyebabkan ikan stres. Ketika ikan mempertahankan hidupnya karena stres maka pakan yang dimakan digunakan untuk pertahanan tersebut yang mengakibatkan pertumbuhan menurun.

\section{Derajat Kelangsungan Hidup}

Derajat kelangsungan hidup benih ikan gurami dengan pemberian dosis rosella yang berbeda pada pakan menghasilkan kelangsungan hidup yang berbeda antar perlakuan, hal ini terjadi karena pakan yang diberi rosella akan meningkatkan imunitas terhadap serangan penyakit karena rosella mengandung vitamin $\mathrm{C}$ yang tinggi.

Selama masa percobaan, kelangsungan hidup terendah terdapat pada perlakuan A (pakan tanpa pemberian rosella), hal ini dikarenakan perlakuan A tidak ada pemberian rosella sehingga kekebalan tubuh ikan gurami lebih rendah dibandingkan perlakuan yang lain. Derajat kelangsungan hidup setiap perlakuan tercantum pada Gambar 2.

Gambar 2 dan Tabel 2 memperlihatkan derajat kelangsungan hidup tertinggi ditemukan pada perlakuan B (20 g rosella/kg pakan) dan perlakuan $\mathrm{C}(30 \mathrm{~g}$ rosella/kg pakan), hal ini terjadi karena perlakuan $\mathrm{B}$ dan $\mathrm{C}$ ada pemberian rosella pada pakan yang mengandung vitamin $\mathrm{C}$ tinggi yang pada hakikatnya vitamin $\mathrm{C}$ dapat membantu mempertahankan hidup terutama hidup ikan gurami. Menurut Henrique et al. (1998) dalam Sandra et al. (2002) vitamin C dapat meningkatkan ketahanan tubuh ikan terhadap stres.

Kelangsungan hidup benih ikan gurami selama masa percobaan tidak berbeda dengan penelitian sebelumnya (Febrianthi 2012) yaitu tertinggi pada perlakuan $20 \mathrm{~g}$ rosella/ $\mathrm{kg}$ pakan sebesar $85,3 \%$ dan penelitian ini tertinggi pada perlakuan 20 dan $30 \mathrm{~g}$ rosella/kg pakan sebesar $68,88 \%$ dan $72,50 \%$, yang terbaik pada penelitian ini yaitu pada perlakuan $20 \mathrm{~g}$ rosella/kg pakan karena hasilnya lebih rendah daripada perlakuan $30 \mathrm{~g}$ rosella/kg pakan dilihat dari segi ekonomi. Namun dilihat berdasarkan angka, penelitian sebelumnya menghasilkan angka lebih tinggi dibandingkan penelitian ini, hal ini terjadi karena pada penelitian ini padat tebar lebih tinggi sehingga 
terjadi persaingan oksigen yang menyebabkan ikan stres, ketika ada stres dari luar ikan mulai mengeluarkan energinya untuk bertahan dari stres sehingga pakan yang diberi rosella dimanfaatkan untuk pertahanan hidupnya. Dampak dari stres tersebut ketahanan tubuh menurun dan mengakibatkan kematian. Selama masa percobaan terdapat beberapa gejala klinis sebelum ikan mati yaitu gerakan tidak berorientasi, warna tubuh menghitam, dan mengeluarkan lendir pada permukaan kulitnya

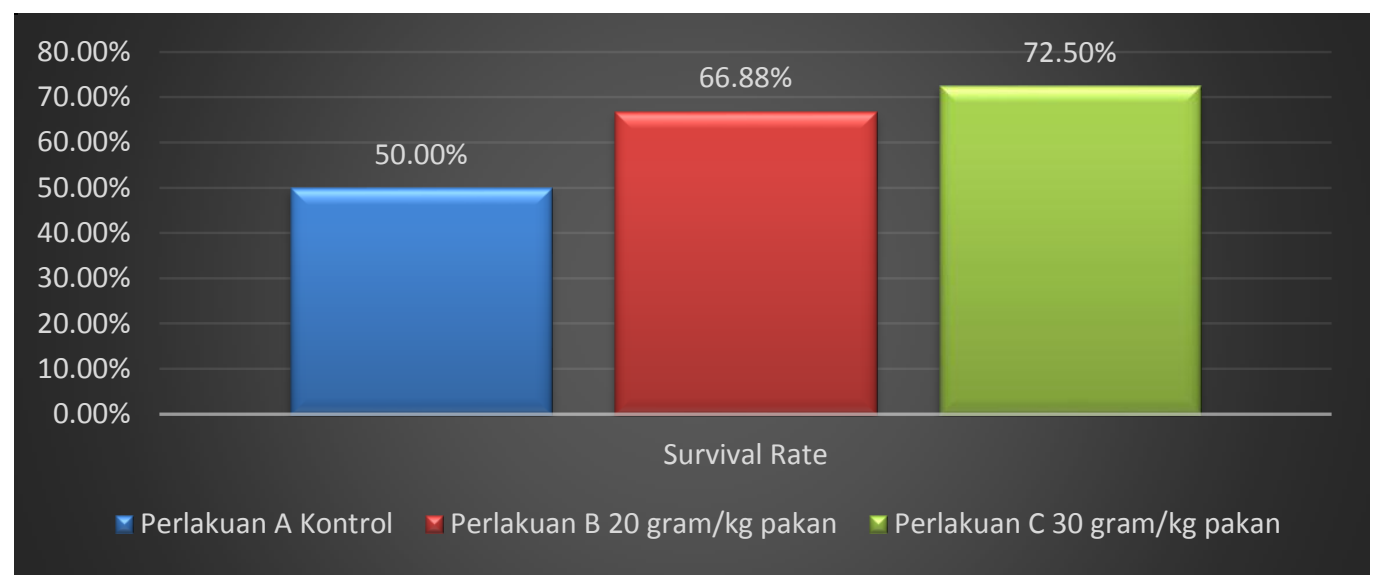

Gambar 2 Derajat kelangsungan hidup setiap perlakuan selama percobaan

\section{Efisiensi Pakan}

Efisiensi pakan benih ikan gurami terendah diperoleh pada perlakuan A (pakan tanpa rosella) sedangkan tertinggi pada perlakuan B (20 g rosella/kg pakan) dan perlakuan C (30 g rosella/kg pakan). Rendahnya efisiensi pakan pada perlakuan A dikarenakan tidak ada pemberian rosella pada pakan. Hasil ini memperlihatkan adanya keselarasan dengan pertumbuhan dimana efisiensi pakan terbaik memberikan pertumbuhan terbaik, sehingga pemanfaatan pakan untuk pertumbuhan pada ikan yang diberi rosella lebih baik dibandingkan pakan tanpa rosella. Menurut Uktolsega (2008) dalam Handajani (2011) menyatakan bahwa keefisienan penggunaan pakan menunjukkan nilai pakan yang dapat berubah menjadi pertambahan pada berat badan ikan. Efisiensi pakan setiap perlakuan dapat dilihat pada Gambar 3.

Efisiensi pakan berbeda pada tiap perlakuan (Gambar 3 dan Tabel 3) dikarenakan pengaruh dari kadar vitamin $\mathrm{C}$ dalam rosella. Pada perlakuan 20 dan $30 \mathrm{~g}$ rosella/kg pakan memberikan nilai efisiensi pakan tertinggi, hal ini mungkin terjadi karena jumlah vitamin $\mathrm{C}$ dalam pakan cukup untuk pertumbuhan yang baik, sedangkan perlakuan $0 \mathrm{~g}$ rosella/kg pakan kandungan vitamin $\mathrm{C}$ nya masih kurang mendukung untuk pertumbuhan yang baik.
Efisiensi pakan pada penelitian ini tidak berbeda dengan penelitian sebelumnya (Febrianthi 2012) yaitu tertinggi pada perlakuan $20 \mathrm{~g}$ rosella/kg pakan sebesar 48,7 $\%$ dan penelitian ini tertinggi pada perlakuan 20 dan $30 \mathrm{~g}$ rosella/kg pakan sebesar $17,729 \%$ dan $17,754 \%$, namun yang terbaik yaitu pada perlakuan $20 \mathrm{~g}$ rosella/kg pakan. Berdasarkan angka, efisiensi pakan penelitian sebelumnya menghasilkan angka lebih tinggi dibandingkan penelitian ini, hal ini terjadi karena penelitian ini padat tebarnya lebih tinggi mengakibatkan ruang gerak sempit yang menyebabkan ikan stres. Stres tersebut berpengaruh terhadap pertumbuhan dan pemanfaatan pakan, yang mengakibatkan pakan lebih banyak dimanfaatkan untuk bertahan dari stres dibandingkan untuk pertumbuhan.

\section{Kualitas Air}

Kisaran kualitas air selama penelitian umumnya baik untuk pertumbuhan dan kehidupan ikan gurami. Kualitas air selama pengamatan menunjukkan kisaran suhu antara $28^{\circ} \mathrm{C}-31^{\circ} \mathrm{C}$, oksigen terlarut (DO) antara 4,22 4,55 ppm, karbondioksida $\left(\mathrm{CO}_{2}\right)$ antara 1,571,98 ppm, $\mathrm{NH}_{3}$ antara 0,030-0,048 ppm, dan $\mathrm{pH}$ antara 7,0-7,4. Hal di atas sesuai dengan pernyataan Bachtiar (2010), ikan gurami cocok hidup di dalam air yang memiliki $\mathrm{pH}$ 6,5-7,0 dan kesadahan lunak sekitar $7 \mathrm{dH}$. Suhu 
optimum untuk pemeliharaan ikan gurami adalah $28-32^{\circ} \mathrm{C}$, kandungan oksigen terlarut minimum $4 \mathrm{mg} /$ liter dengan tingkat kecerahan air $40-60 \mathrm{~cm}$. Batas konsentrasi kandungan amoniak yang dapat menyebabkan kematian gurami adalah 0,1-0,3 $\mathrm{mg} / \mathrm{liter}$ air dan kandungan karbondioksida $\left(\mathrm{CO}_{2}\right)$ maksimal 5 mg/liter (Khairuman dan Amri 2003).

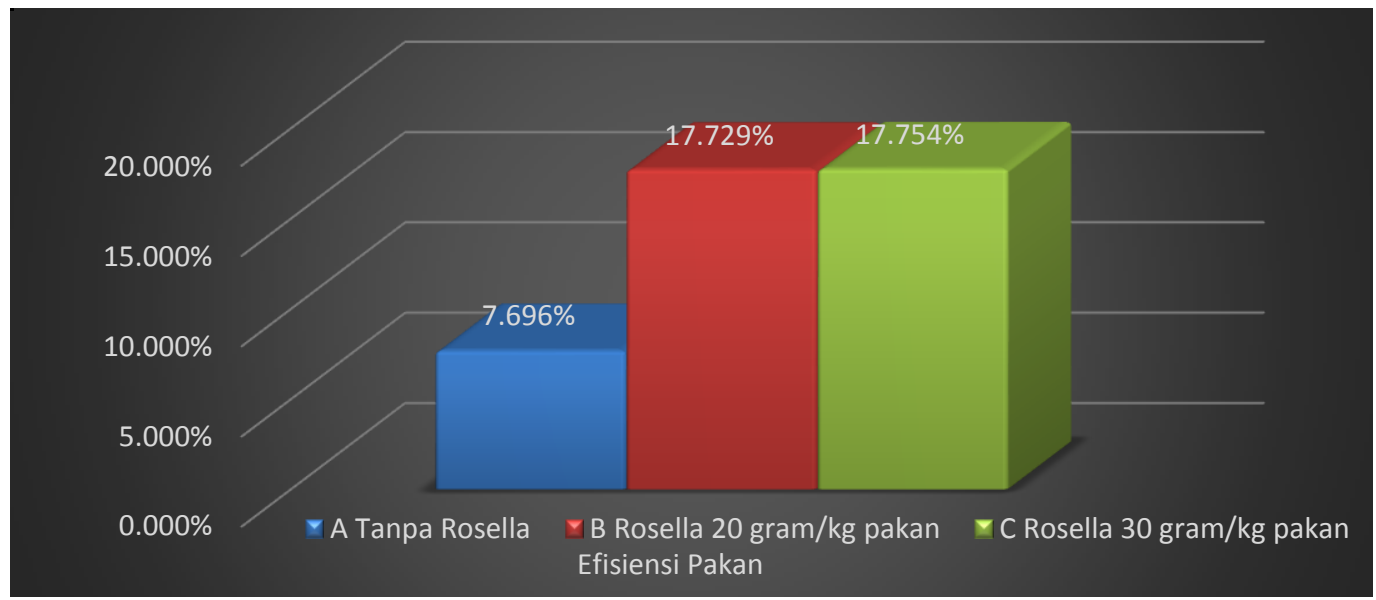

Gambar 3 Efisiensi pakan setiap perlakuan selama masa percobaan

\section{Kesimpulan}

\section{KESIMPULAN DAN SARAN}

Hasil yang diperoleh selama masa percobaan adalah berbeda nyata $(\mathrm{P}<0,05)$ terhadap laju pertumbuhan harian, kelangsungan hidup, dan efisiensi pakan. Laju pertumbuhan harian, derajat kelangsungan hidup, dan efisiensi pakan tertinggi terdapat pada perlakuan $\mathrm{B}(20 \mathrm{~g}$ rosella/kg pakan $)$ sebesar 1,041\%, 68,88\%, 17,729\% dan perlakuan C (30 g rosella/kg pakan) sebesar $1,047 \%, \quad 72,50 \%, \quad 17,754 \%, \quad$ sedangkan terendah pada perlakuan A (pakan tanpa rosella) sebesar $0,483 \%, 50,00 \%, 7,696 \%$.

\section{Saran}

Diharapkan ada penelitian lanjutan dengan padat penebaran berbeda pada setiap perlakuan.

\section{DAFTAR PUSTAKA}

Bachtiar Y. 2010. Budidaya dan Bisnis Gurami. Jakarta: Agromedia Pustaka.

Darmansyah MA. 2011. Pertumbuhan dan Kelangsungan Hidup Lobster Air Tawar (Cherax quadricarinatus) pada Pendederan di Dalam Bak dengan Padat Penebaran 100 hingga 175 ekor $/ \mathrm{m}^{2}$. Skripsi. Fakultas Perikanan dan Ilmu Kelautan. Institut Pertanian Bogor. Bogor.
Darmawangsa GM. 2008. Pengaruh Padat Penebaran 10, 15 dan 20 ekor/L terhadap Kelangsungan Hidup Dan Pertumbuhan Benih Ikan Gurami Osphronemus gouramy Lac. Ukuran $2 \mathrm{~cm}$. Skripsi. Program Studi Teknologi Dan Manajemen Akuakultur. Fakultas Perikanan dan Ilmu Kelautan. Institut Pertanian Bogor. Bogor.

Effendie MI. 1979. Metoda Biologi Perikanan. Bogor: Yayasan Dewi Sri.

Febrianthi P. 2012. Pengaruh Penambahan Bunga Rosella (Hibiscus sabdariffa L.) pada Pakan Terhadap Pertumbuhan dan Kelangsungan Hidup Ikan Gurami (Osphronemus gouramy Lac.). Skripsi. Jurusan Teknologi Budidaya dan Bisnis Perikanan. Fakultas Agribisnis dan Teknologi Pangan. Universitas Djuanda Bogor. Bogor.

Handajani H. 2011. Optimalisasi Substitusi Tepung Azolla Terfermentasi pada Pakan Ikan untuk Meningkatkan Produktivitas Ikan Nila Gift. Jurnal Teknik Industri, Vol.12, No.2, Hal 177181. 
Khairuman, Amri K. 2003. Pembenihan dan Pembesaran Gurami Secara Intensif. Jakarta: Agromedia Pustaka.

Mardiah, Rahayu A, Ashadi RW, Hasibuan S. 2009. Budi Daya dan Pengolahan Rosella. Jakarta: Agromedia Pustaka.

Sandra H, Jusadi D, Mokoginta I. 2002. Pengaruh L-Askorbil-2-Fosfat Magnesium terhadap Kemampuan Tubuh Mengatasi Stres dan Pertumbuhan Ikan Baung Mystus nemurus. Jurnal
Akuakultur Indonesia, Vol.9, No.4, Hal 125-129.

Saparinto C. 2011. Panduan Lengkap Gurami. Jakarta: Penebar Swadaya.

Sastrosupadi A. Rancangan Percobaan Praktis Bidang Pertanian. Yogyakarta: Kanisius.

Standar Nasional Indonesia. SNI : 01-648532000. Produksi Benih Ikan Gurame (Osphronemus gouramy Lac.) Kelas Benih Segar. 